\title{
Hybrid entrepreneurship: The importance of passion
}

\author{
Abstract \\ Purpose -Investigate motives behind individuals’ choice to have parallel business- \\ employment careers (hybrid entrepreneurship) with a particular focus on passion (i.e., to work \\ with something one is passionate about) as the main motive. \\ Design/methodology/approach - A survey was administered to 262 Swedish hybrid \\ entrepreneurs. Hypotheses proposed associations of the individual's age at business start-up \\ and weekly hours spent on the business with passion as the main motive for the hybrid form. \\ Logistic regression was used to test the hypotheses. \\ Findings - The results indicated that (1) the ability to work with something one is passionate \\ about is the top motive for combining employment with a side business; (2) passion is more \\ likely to be the main motive behind the hybrid form among individuals who are older at \\ business start-up; (3) passion is less likely to be the main motive behind the hybrid form \\ among individuals who spend more time on the business. \\ Research limitations/implications - The study focuses on passion as motive for hybrid \\ entrepreneurship, and in doing so, it does not test the extent to which hybrid entrepreneurs \\ experience passion. \\ Practical implications - The results support the popular notion that passion drives people to \\ have parallel business-employment careers. Findings indicating that passion as a motive is \\ more common among those who are older at start-up and less common among those who \\ spend more time on the business suggest the importance of acknowledging hybrid \\ entrepreneurs' various profiles when approaching them in research and practice. \\ Originality/value - This is the first study on motives behind hybrid entrepreneurship. \\ Keywords - hybrid entrepreneurship, passion, logistic regression \\ Paper type - Research paper
}




\section{Introduction}

'Hybrid entrepreneurship', which entails that people keep their wage work while starting a business, is a relatively new stream of research (Campbell and De Nardi, 2009; Delmar, Folta, and Wennberg, 2008; Folta, Delmar, and Wennberg, 2010). In practice, however, it is very common. The 2003 Global Entrepreneurship Monitor (GEM) report indicated that up to 80\% of the nascent entrepreneurs start their business while having a job (Reynolds, Bygrave, and Autio, 2003). While it has been suggested that people do this in the nascent entrepreneurial phase for reasons such as securing income while testing their business idea (Burke, Fitzroy, and Nolan, 2008; Folta et al., 2010), entrepreneurs may maintain the hybrid form long beyond the start-up phase. For example, in the United Kingdom, the hybrid entrepreneurs constitute a larger group than the "pure" entrepreneurs who do not combine their venturing with an employment (Burke et al., 2008). In Sweden, every 10 person aged 20-64 years with full-time or part-time wage work conducts a side business (Statistics Sweden, 2010).

One of the more basic questions regarding hybrid entrepreneurs is why they choose to combine work with a side business. While it has been suggested that the hybrid entrepreneurship enables people to spend time on something they are passionate about (Folta et al., 2010; Herslund and Tanvig, 2012; The Ministry of Industry, Employment and Communication, 2003), there are no empirical tests on whether passion is indeed an important motive for the hybrid form. The paucity of studies that specifically address motives behind the hybrid form is a shortcoming for both theory and practice. From a theoretical viewpoint, knowing entrepreneurs' motives for the hybrid entrepreneurship is an important building block for developing theory and research on hybrid entrepreneurship. Much attention has been paid to reasons for being an entrepreneur, such as innovation, independence, and financial success (Carter, Gartner, Shaver, and Gatewood, 2003); however, entrepreneurs who are both employed and self-employed may have different reasons for being entrepreneurs. From a 
practical viewpoint, the lack of studies on the motives for combining wage work and a business may hamper the public understanding of hybrid entrepreneurship. For instance, in a time when the European Union invests in massive programs ${ }^{1}$ aimed to encourage business start-ups in addition to the national governments' support programs, the lack of knowledge of hybrid entrepreneurship is a shortcoming. With the lack of scientific studies on the topic, public misconceptions may develop on where entrepreneurs can be found, how they operate, and why they make the choices they do. Such misconceptions can be detrimental to the public dialogue on entrepreneurship, especially when considering the heavy investments in entrepreneurship support programs.

The primary purpose of the present study is to provide knowledge of the motives behind individuals' choice to combine their wage work with a side business, with a particular focus on passion (i.e., to work with something one is passionate about) as the main motive. We begin by discussing the nature of passion. We then develop theoretical arguments regarding two significant factors in hybrid entrepreneurship: the individual’s age at start-up and time spent on the venture. In particular, we integrate theoretical insights from the general entrepreneurship and psychology literatures with Conservation of Resources (COR) theory to argue that hybrid entrepreneurs who are older are more likely to consider passion as their main motive for combining the employment with a side business and that passion is less likely to be the main motive among hybrid entrepreneurs who spend more time on the business.

\footnotetext{
${ }^{1}$ For illustration, the European Commission plans a budget of $€ 2$.3bn for the program Competitiveness of Enterprises and Small and Medium-sized Enterprises (COSME) to be run 2014-2020.
} 


\section{Theoretical framework and hypothesis development}

As defined in the entrepreneurship literature (Cardon, Wincent, Singh, and Drnovsek, 2009), passion is a “consciously accessible, intense positive feeling.... and results from engagement in activities with identity meaning and salience to the entrepreneur” (p. 515). We develop a theoretical framework that addresses potential determinants of passion as the main motive for combining wage work with a side business. Passion is a relatively recent concept in both psychology and entrepreneurship research.

In psychology research, the Vallerand, Blanchard, Mageau, Koestner, Ratelle, Léonard, Gagné, and Marsolais’s (2003) Dualistic Model of Passion (DMP), which suggests that there are two types of passion (harmonious and obsessive), has received much attention. While the DMP research has focused mostly on studying different outcomes from harmonious/obsessive passion (e.g., well-being, positive/negative affect), only a handful of DMP studies focus on antecedents of passion. Those studies typically concentrate on how the activity that the individual is passionate about became part of their identity and whether the individual has an autonomous or controlled personality (Vallerand, Rousseau, Grouzet, Dumais, Grenier, and Blanchard, 2006).

In the entrepreneurship and management research, some studies build on the DMP (e.g., Ho, Wong, and Lee, 2011; Klaukien, Shepherd, and Patzelt, 2013; Thorgren and Wincent, in press; Omorede, Thorgren, and Wincent, 2013), whereas other studies draw rather on more context specific works, such as Baum and Locke (2004) and Cardon et al.'s (2009) conceptual framework on entrepreneurial passion (Cardon, Gregoire, Stevens, and Patel, 2013). However, regardless of the framework used, the extant research has focused on examining variance in the extent of experienced passion and its outcomes. In the present study, it would thus be necessary to go beyond the literature on passion to identify 
antecedents and mechanisms for the hybrid form and to examine empirically how likely passion will constitute the main motive for combining wage work and a business.

In pioneering research on passion as a motive behind hybrid entrepreneurship, we have selected two factors to focus on: 1) the hybrid entrepreneur's age at business start-up and 2) time devoted to the business. The age variable was selected because previous research, such as the Global Entrepreneurship Monitor (GEM), has suggested that it is important to consider the age at which an individual enters not only hybrid entrepreneurship, but also entrepreneurial endeavors (Reynolds, Bygrave, Autio, Cox, and Hay, 2002). However, when reviewing entrepreneurship research, the entrepreneur's age is typically used only as a control variable (e.g., Petrova, 2012; Raffiee and Feng, in press). Few studies theorize about the mechanisms and effects of age on the transition to self-employment (for an exception see Blanchflower and Meyer [1994] who argued that younger people are likely to transition to self-employment). The variable capturing time spent on the business was selected because it is one of the main topics of discussion in the hybrid entrepreneurship literature (Campbell and De Nardi, 2009; Kimmel and Smith Conway, 2002; Renna, 2006), but no research has integrated it with theory to understand its effects on perception, attitudes, and performance. The selected two variables are thus likely to be important for gaining an understanding of the mechanisms behind hybrid entrepreneurship. Nevertheless, the aforementioned limitations necessitate a theoretical framework which is not strictly based on passion and hybrid entrepreneurship research.

To build the theoretical argumentation for how and why the age and time variables will affect passion as a motive behind hybrid entrepreneurship, Hobfoll’s (1989, 2001) Conservation of Resources theory is used as a primary building block together with arguments from psychology and general entrepreneurship research. COR theory builds on the assumption that people strive to obtain, retain, and protect resources to mitigate stress and 
accomplish things in life (Grandy and Cropanzano, 1999; Taris, Schreurs, and Schaufeli, 1999). In COR theory, resources can be categorized into objects (e.g., physical assets), favorable conditions (e.g., a good marriage), personal characteristics (e.g., self-esteem), and

energies (e.g., money). The core idea is that overly high environmental demands and personal shortcomings that are needed to meet these demands are likely to deplete resources for successful coping with challenges. Ultimately, this reduces the necessary motivation for completing tasks and other important personal and professional assignments. COR theory is meaningful for the purpose of the present study because it has a clear connection to positive affect and identity associations, which are two important elements of passion (Thorgren and Wincent, 2013). By proposing that resource gain stimulates a behavioral approach system, including positive emotions and state/trait driven behaviors, and that resource loss stimulates a behavioral inhibition system, including negative emotion and situationally constrained behavior (Keltner, Gruenfeld, and Anderson, 2003), COR theory enables the integration of important conditions necessary for passion to develop. Through positive affective behavioral processes, this system makes individuals feel positive about pursuing risks while seeking rewards. The COR theory is found adequate for studying passion in hybrid entrepreneurship since both resource gain and resource depletion are linked to entrepreneurial intentions (Hayton and Cholakova, 2012) and involve necessary risk-propensity for being motivated to engage in entrepreneurship (Brindley, 2005; Fletcher, 2010; Monsen and Urbig, 2009). Below, we theorize about the ways in which the age at start-up is likely to stimulate approach behaviors, whereas time spent on the business is likely to stimulate inhibition.

\section{Age at start-up}

Considering the COR theory, one can consider the time before business start-up as a time for resource gain. This means that the entrepreneur who is older at business start-up has 
gained more resources and has felt more positive about approaching risk for possible future rewards, which is important for enjoying venturing (Fletcher, 2010). In general, it can be expected that all four kinds of resources (objects, conditions, personal characteristics, and energies) improve with age (Grandey and Cropanzano, 1999; Parasuraman, Greenhaus, and Granrose, 1992), which has been a topic of entrepreneurship research. Kautonen, Down, and Minniti (2013) showed how older individuals have accumulated knowledge, social capital, and assets that make them better equipped for coping with challenges and enjoying necessary risks related to combining their employment with a business. For the objects category, those who are older at start-up may own a greater number of physical assets, giving them a better socio-economic status. For the conditions resources, it is likely that those who are older have a richer set of resources through family-building and prior careers. These conditions, which facilitate stability, may be valuable, and they can help obtain other resources (Hobfoll, 1989). For example, older entrepreneurs could take advantage of their social networks built in previous and current employment and private domains (Greve and Salaff, 2003). In terms of personal characteristics, self-efficacy (i.e., trust that one can cope with challenging situations) and a feeling of belongingness is likely to develop with age (Richardson, 2002). Finally, one can see that younger entrepreneurs may feel financial constraints, such as difficulties getting bank loans or finding other investors (Campbell and De Nardi, 2009).

These resource limitations that younger entrepreneurs face are likely to result in behavioral inhibition; thus, mitigate the necessary conditions for enjoying higher levels of risk-taking and for developing passion. Without a solid resource pool for taking the necessary risks in venturing, positive feelings for combining employment with a business may not develop. In support of this behavioral inhibition argument, Langowitz and Minniti (2007) suggested that low willingness to take risk mitigates the strong motivation needed to commit resources to long-term venturing. Moreover, Monsen and Urbig (2009) found that resources 
available for venturing increase approach-related behaviors and consequently risk-taking and motivation for running a business. As passion is considered one of the core motivators of entrepreneurship, it is likely to expect that resources that enable higher risk-taking in venturing are important for passion to become the main driver.

In summary, the above arguments suggest that the resource bank built over time may make older hybrid entrepreneurs better equipped for the challenges associated with their multiple roles. Older hybrid entrepreneurs can resist feelings that demands are exceeding their resources, they can be more comfortable to take necessary risks in venturing, and they may also be better at generating new resources when they are in stressful situations (Hobfoll and Lilly, 1993). This, in turn, enables positive feelings such as passion for the business. Thus, we hypothesize:

H1: The older hybrid entrepreneurs are at business start-up, the more likely the wage work/business combination is driven by passion.

\section{Time spent on the business}

Time spent on the business may be considered as resource loss, and it may increase the risk of inhibition, with negative emotions as a consequence (Keltner et al., 2003). Whereas it is well known that entrepreneurs face challenges with combining their work and family (Binder and Coad, 2013; Thorgren and Wincent, 2013), hybrid entrepreneurs have even more roles to cope with since their work life consists of both wage work and running a business. The more time they spend on the work roles, the less time they spend together with family and friends (Parasuraman and Simmers, 2001). While it may not be a problem to spend some time on the business, similar to spending time on any hobby or leisure activity, individuals who are highly involved in their work will have difficulties balancing multiple roles 
(Halbesleben, Harvey, and Bolino, 2009). The competition for the individuals’ limited time (Major, Klein, and Ehrhart, 2002) implies that individuals who spend extensive time on the business have less energy and time for the family and other activities (Halbesleben et al., 2009). This is likely to activate inhibition, which means that these individuals are less likely to feel the positive feelings of passion while being attentive to threats and more exposed to constraints. In the entrepreneurship setting, work-family conflicts have been reported as detrimental to the entrepreneurial experience and positive perceptions of necessary risks in venturing (Wincent and Örtqvist, 2009). The entrepreneurs who spend more time on the business are likely to experience greater resource loss and perceive that demands are exceeding the resources. This is something that reduces the willingness to take further risks and thus the feelings of positive emotions towards venturing, such as passion (Cardon et al., 2009). Moreover, when work-family conflict intensifies, this potentially reduces the salience of the business to the individual's self-concept (Arenius and Minniti, 2005). When resources are stretched this way, negative loss-cycles might be set off, which may be very stressful for the individual (Hobfoll and Lilly, 1993; Wells, Hobfoll, and Lavin, 1997; Wells, Hobfoll, and Lavin, 1999) and consequently leave little room for accepting the increased risks of entrepreneurship and experiencing positive feelings, such as passion to thrive. Formally stated:

H2: The more time hybrid entrepreneurs spend on the business, the less likely the wage work/business combination is driven by passion 


\section{Research methods}

\section{Sample and data collection}

Hypotheses were tested on 262 hybrid business owners in Sweden. Because no separate mailing list or register lists only hybrids, we had to identify the sample manually to some extent. First, we decided to focus on entrepreneurs in the counties of Gävleborg and Jämtland, which are located outside any metropolitan areas. Previous research (Delmar et al., 2008) has shown that people may depend more on hybrid entrepreneurship to earn a living in nonmetropolitan areas. We focused particularly on entrepreneurs in the creative industry, including architecture, computer and video games, design, film, photography, art, literature, media, music, food, arts, business communications, fashion, tourism industries, and experiential learning (an exhaustive list of the Swedish industry classification codes used can be provided by the second author). The creative industry was chosen because hybrid entrepreneurs are especially important in this type of industry (Trip and Romein, 2013).

We used services from The Statistics Sweden to generate a list with contact information for all business owners within the creative industry in those two counties, retrieving information on 1,735 business owners. Based on the returned mail, it turned out that 278 of them had either closed down or changed address, yielding an adjusted total sample of 1,457 business owners. We received usable questionnaires from 455 business owners, resulting in a response rate of 31\%. The questionnaire responses indicated that 262 of them were hybrid entrepreneurs (58\% of the sample); thus, this study drew on the data collected from these entrepreneurs. The respondents' age at the time of data collection was categorized into 5 groups, $20-30$ years $=9 \%$; $31-40$ years $=22 \%$; $41-50$ years $=27 \%$; $51-60$ years $=30 \%$; and $60+$ years $=12 \%$. 


\section{Motives behind hybrid entrepreneurship}

To capture the motives for hybrid entrepreneurship, the respondents were asked to select an option, from a list of options, which best represents their main motive for combining an employment with a running a business. This option list was developed through a series of activities. First, we reviewed the general literature on the reasons for entrepreneurship (e.g., Carter et al., 2003). Thereafter, unstructured interviews were conducted with five hybrid entrepreneurs to discuss the reasons typically mentioned in the traditional entrepreneurship literature and to identify other possible motives for hybrid entrepreneurship. Those discussions resulted in a long list of motives, which then underwent peer scrutiny before conducting pre-tests of the entire questionnaire. After the pre-tests, the motive list was reduced to 15 motives plus an open “Other motive” option. Table 1 lists the final options and their distribution among respondents. As Table 1 shows, the motive "To work with something I am passionate about” was the most frequently indicated motive (34\%) for combining wage work with a business. This is followed by the motives "Earn money" (16\%) and "I enjoy the business/work combination” (13\%). The final option “Other motive” (5\%) generated various responses, which did not fit into any of the other 15 motives (e.g., including hybrid entrepreneurs who combined wage work and business because of cancer; uncertain employment; and a tradition in certain professions, such as architects, to take on side projects). 


\section{Dependent and independent variables}

In the next step, the responses to the motive list in Table 1 were used to calculate the dependent variable, passion, as a driver of combining wage work and a business ${ }^{2}$. The responses were coded as 1 when the respondent selected "To work with something I am passionate about" as the main motive and 0 when the respondents selected any of the other 15 options. The independent variable age referred to the entrepreneurs' age at the time of business start-up. The time variable captured the time spent weekly on the business. The control variables were gender $($ women $=0$, men $=1$ ); current age; married/cohabitating (not married $/$ cohabitating $=0$, married/cohabitating $=1$ ); children $($ no $=0$, yes $=1)$; and university degree (no $=0$, yes $=1)$.

\section{Focus interviews}

After collecting and analyzing the data, focus interviews were carried out to validate the questionnaire (Jackson and Holbrook 1995) and to receive additional insights. Using focus groups can be a highly efficient way to explore the context and to gain a better understanding of the hybrid situation. They can provide information to contribute to a better understanding of the topic and expand the existing knowledge (Gibson-Graham 1994; Goss and Leinbach, 1996).

Based on respondents who had accepted to participate in a follow-up study (final question in the questionnaire), eight focus groups were formed. Because of the difficulties to find a time suitable for hybrid entrepreneurs, more people were contacted for each interview

\footnotetext{
${ }^{2}$ Notably, there are passion scales available which could be employed for approaching other research questions where the extent of experienced passion is relevant to capture. The Vallerand et al (2003) scale is well established in psychology literature and has the benefit of separating harmonious passion and obsessive passion, and in doing so highlighting whether the person is in control of the passion or if the passion controls the person. For studies on entrepreneurial passion, the new scale by Cardon, et al. (2013) can be used for highlighting integration between positive feelings and identity centrality in relation to entrepreneurship.
} 
than necessary. Typically, three people were able to attend out of eight to ten people who were invited to participate in each focus group interview. Five focus interviews were held in the Gävleborg county and three in the Jämtland county. The 27 interviewees (19 men; 8 women) represented various trades and occupations, and their age spanned from 37 years to 66 years. All focus group interviews followed a guide, generating stimulating discussions on general themes from the questionnaire: Individual characteristics; Business engagement, wage work engagement, and their combination; Work-business link; and Reasons for being a hybrid. All eight interviews, lasting for about two hours and thirty minutes, were audiorecorded and later transcribed in full. The qualitative data software Nvivo was used to identify common patterns.

\section{Results}

Table 2 reports the means, standard deviations, and correlations of all study variables. To test the hypotheses, a logistic regression analysis was used. Although no correlations passed critical thresholds of associations between independent variables, a variance inflation factor (VIF) was used to test multicollinearity in the subsequent models. VIF values below 2.5 indicated no multicollinearity issues.

\section{--INSERT TABLE 2 ABOUT HERE --}

We used logistic regression to test the hypotheses, and the results are shown in Table 3. In Model 1, only the controls were included. To test the effects of the hybrid entrepreneur's age at start-up and time spent on the business, those variables were added in Model 2. The results support Hypothesis 1; passion is more likely to motivate hybrid entrepreneurs who are older at business start-up to combine wage work and a business $(\beta=.619, \mathrm{p}<0.05)$. Hypothesis 2 predicted that passion is less likely to drive the wage work/business combination when entrepreneurs spend more time on the business. As shown in Model 2, the significant coefficient for time spent $(\beta=-.429, \mathrm{p}<0.01)$ supports Hypothesis 2 . 
Table 4 presents additional descriptive information on hybrid entrepreneurs' time spent on the business. Taking children/no children into account, it demonstrates that male hybrid entrepreneurs without children spend the greatest amount of time on the business (24 hours per week on average). Among those who have children, women spend the greatest amount of hours on the business when their children are 20 years or older, whereas men spend more time on business when the children are in their teens. Considering age, Table 4 reveals that women spend the greatest amount of time on their business when they are in their 50s and men when they are in their 30s and 60s.

\section{--INSERT TABLE 4 ABOUT HERE --}

We consulted several post-hoc analyses to validate our main results. First, we retested the effects of age and time on passion using different variables, such as the children's age groups, controlling for the other motives, and assessing the effects of counties. We noticed that no control variable in our data significantly changed the main results of the study. Further, our analyses demonstrated no significant effects of the various industry orientations (e.g., publishing, music, literature) on passion.

Second, we used our focus interviews to validate our results. Table 5 presents the themes and main insights relevant for the present study’s aim. Overall, the focus interviews supported the questionnaire's validity. It was clear that the age when the hybrid entrepreneurs started their business was important for the passion motive, and we found consistent evidence supporting our explanation provided in the theory section. A statement that was mentioned repeatedly was that they had the business idea long before they started the business, but they thought about it carefully for a long time. Because the start-up was slow, it became clear to them that the longing for working with something they were passionate about was the main motive, otherwise they would have started up the business much earlier. We also found 
support for our qualitative explanation of causal effects of time spent on business and passion. Overall, our interviews suggest that hybrid entrepreneurs who invest a lot of time in the business may risk losing their passion because of problems with managing role conflicts and coping with the stress as well as with finding a balance between family and work. The statements were much in line with the work-family conflict avoidance in the COR-model, which was used to guide our hypotheses.

\section{--INSERT TABLE 5 ABOUT HERE --}

The plot of relevant key variables in the above statements shows a similar picture. As presented in Figure 1, young people who are driven by passion spend an average of fifteen hours per week on the business while those over thirty years of age spend less. A natural explanation would be that those who are over thirty years of age try to reduce role conflicts arising from having small children. During the focus interviews, several respondents mentioned that the problem working with something that is close to the heart is that too much time is spent on it, and for many it has resulted in extended sick leave because of burnout. Their professional engagements developed into a manic behavior, where the family life was at loss because of their devotion to their work for both wage work and a business.

\section{Discussion}

The present study's primary purpose was to provide knowledge of the motives behind individuals' choice to combine their wage work with a side business (hybrid entrepreneurship), with a particular focus on passion (i.e., to work with something one is passionate about) as the main motive. Two factors, the hybrid entrepreneur's age at business start-up and the time spent weekly on the business, were theorized to influence the likelihood that combining of wage work and running a business is driven by passion. The results indicated that (1) the ability to work with something one is passionate about is the top motive 
for combining wage work with a side business; (2) passion is more likely to be the main motive for hybrid entrepreneurship among individuals who are older at the business start-up; (3) passion is less likely to be the main motive for hybrid entrepreneurship among individuals who spend more time on the business.

\section{Implications for theory}

This study contributes to the theory and research on entrepreneurs in numerous ways. It acknowledges that many entrepreneurs are hybrids in that they run a business along with taking up an employment. While hybrids are typically not excluded from examined entrepreneur samples in entrepreneurship research, they are rarely given particular focus. This is a shortcoming since the hybrid form is very common in practice, and research on entrepreneurship in general may not apply to it. To increase the understanding of hybrid entrepreneurs, it is essential to inquire about the motive for engaging in the hybrid entrepreneurship. While previous studies have mentioned various motives (e.g., Campbell and De Nardi, 2009; Folta el al., 2010; Raffiee and Feng, in press), the present study is the first to explore this question empirically. We found that among the sampled entrepreneurs, the most common motive was that they wanted to feel passionate about their work. While passion is often included as an important motivator when discussing hybrid entrepreneurs, our empirical data contributes to the literature, as it indicated that passion is the strongest motive for hybrid entrepreneurship (34\%). The second motive was "Earn money” (16\%) followed by “I enjoy the business/work combination.” Thus, hybrid entrepreneurs who enjoy the combination may not have the intention to quit their job, and this is something that the theory development on hybrid entrepreneurs would need to capture.

The results of the hypothesis testing provide implications for the understanding of hybrid entrepreneurship. The two variables tested-age at start-up and time spent on the 
business - are generic variables, which are commonly controlled. In the present study, we acknowledged their role in passion driving the hybrid entrepreneurship. We suggested that persons who are older at venture start-up have more resources for taking on the risks and meeting the challenges associated with combining an employment with a business. Their gathered resources will stimulate positive feelings, such as passion, for being a hybrid entrepreneur. Considering that the hybrid entrepreneurs are also employed for wages, those who spend much time on the business are under higher constraints, which stimulates negative emotions, implying that passion is not likely to drive the hybrid entrepreneurship. Initial evidence suggests that those two notions are important factors for understanding hybrid entrepreneurship. The results indicated that the passionate motive might depend much on the resources of the hybrid entrepreneur. Thus, a question for future research is not only to test passion as a motive, but also to test the extent to which hybrid entrepreneurs experience passion and identify the factors that may influence whether they are scoring high or on low on passion. Moreover, the consequences of a shift from passion as main motive to another motive, such as earning money, have on the wage work, business, and the individual should be explored. The present study is the first to introduce the passion concept to hybrid entrepreneurship and show that it plays a significant role; however, additional research should further this understanding.

\section{Implications for practice}

The present study gives policy makers important new information on hybrid entrepreneurship. The results of the study indicated that the most prominent motive for hybrid entrepreneurship is that people want to be passionate about their work. This is important in order to know what can be done to encourage the continued business and growth of hybrid entrepreneurs. Hybrid entrepreneurs combine their employment with a business mainly 
because they feel passion for it and may not have ambition to pursue an entrepreneurship career based only upon a profit motive. Although research has not particularly looked into this question, the present study result aligns well with previous findings. In the long-term, hybrid entrepreneurs usually operate on a small-scale, and they secure and add to their income through self-realization and creativity (Delmar et al., 2008; Folta et al., 2010; Wennberg, Folta, and Delmar, 2006). They open a side business to address their interests and extend or develop their hobbies (Renna, 2006). They choose the amount of time they spend on sidebusiness as well as the kind of products/services they offer in their own business (Delmar et al., 2008). This means that policies that discuss tax-cuts for stimulating hybrids into selfemployment and leave wage work behind may be of limited effectiveness. As highlighted previously, in many cases, profit is not behind the decision to pursue venturing. This raises a question: To what extent should stimulation and policy efforts be required of policy to stimulate hybrids into self-employment and is this efficient for the economy as a whole? The answer to this question is likely to vary from one country or industry to the next and depend on the type of wage work in which a hybrid entrepreneur engages.

Moreover, the study showed that the passionate drive is stronger among those who are older at the start-up and spend less time on the business. This means that the study finds support for an underlying theoretical assumption of resource conservation, suggesting that the broad domain of personal resources, which hybrid entrepreneurs have at hand, is important for understanding their main motive for combining their traditional wage work with entrepreneurship. If factors and circumstances take toll on these resources, their passion for hybrid entrepreneurship is likely to diminish. This suggests that effective resource conservation, such as being older when starting the venture and not being in a situation in which the hybrid entrepreneur needs to spend too much time on venturing, may make the passion, as the main motive for hybrid entrepreneurship, last for several years beyond start- 
up. This suggests that passion in hybrid entrepreneurship is likely to depend on many factors tied to both the wage work and the business. While these implications are open for further examination and interpretation, they may suggest that policy makers should pay unique attention to hybrid entrepreneurs. This can facilitate more effective entrepreneurship programs directed toward hybrid entrepreneurs.

\section{Limitations and future research}

Some limitations should be considered. The sample used consisted of hybrid entrepreneurs in two Swedish counties, and care should therefore be taken before generalizing to other contexts. However, the distribution of general demographic variables (such as, age, gender, children, and education) is consistent with the Swedish study by Delmar et al. (2008), which used a broader sample. At a variable level, the control variables were all measured at the time of data collection and family characteristics, such as children and social status, at the time of business start-up may have added additional explanation. We therefore encourage future studies to consider temporal aspects to a greater extent than we have in this study. As with any survey results, concerns with face validity should be addressed in this study. To mitigate this limitation, the focus groups were used to validate the findings. These groups were also particularly useful for validating the one-item dichotomous measure of the dependent variable. Still, we encourage further research into developing measures that fit the context of hybrid entrepreneurship. Finally, we did not have sufficient access to the financial performance of the hybrid entrepreneurs to analyze such data. However, as was highlighted during the focus interviews, the venture performance may also determine the entrepreneurs' main motives. We therefore suggest that future research investigates the role of the venture performance in the hybrid entrepreneurs' feelings and attitudes toward the wage work/business combination. Besides these limitations, the study still demonstrates that the 
person's age at start-up and time spent on the business are factors to consider in hybrid entrepreneurship research and in passion research, and thus adds important knowledge, which future research can build upon.

\section{References}

Arenius, P. \& Minniti, M. (2005). Perceptual variables and nascent entrepreneurship. Small Business Economics, Vol. 24 No. 3, pp. 233-247.

Baum, J. R., \& Locke, E. A. . (2004). The relationship of entrepreneurial traits, skill, and motivation to subsequent venture growth. Journal of Applied Psychology, 89(4), 587598.

Binder, M. \& Coad, A. (2013). Life satisfaction and self-employment: A matching approach. Small Business Economics, Vol. 40 No. 4, pp. 1009-1033.

Blanchflower, D. G. \& Meyer, B. D. (1994). A longitudinal analysis of the young selfemployed in Australia and the United States. Small Business Economics, Vol. 6, pp.119.

Brindley, C. (2005). Barriers to women achieving their entrepreneurial potential: Women and risk. International Journal of Entrepreneurial Behaviour \& Research, Vol. 11 No. 2, pp. 144-61.

Burke, A. E., FitzRoy, F. R. \& Nolan, M. A. (2008). What makes a die-hard entrepreneur? Beyond the 'employee or entrepreneur' dichotomy. Small Business Economics, Vol. 31 No. 2, pp. 93-115.

Campbell, J. R. \& De Nardi, M. (2009). A conversation with 590 Nascent Entrepreneurs. Annals of Finance, Vol. 5 No. 3-4, pp. 313-340.

Cardon, M. S., Gregoire, D. A., Stevens, C. E., \& Patel, P. C. (2013). Measuring entrepreneurial passion: Conceptual foundations and scale validation. Journal of Business Venturing, Vol. 28 No. 3, pp. 373-396. 
Cardon, M. S., Wincent, J., Singh, J. \& Drnovsek, M. (2009). The nature and experience of entreprenurial passion. Academy of Management Review, Vol. 34 No. 3, pp. 511-532.

Carter, N. M., Gartner, W. B., Shaver, K. G., \& Gatewood, E. J. (2003). The career reasons of nascent entrepreneurs. Journal of Business Venturing, 18(1), 13-39.

Delmar, F., Folta, T. B. \& Wennberg, K. (2008). The dynamics of combining self-employment and employment. Report 2008:22. Stockholm, Sweden: IFAU- Institute for Labor Market Policy Evaluation.

Fletcher, D. (2010), “'Life-making or risk taking’? Co-preneurship and family business startups”, International Small Business Journal, Vol. 28 No. 5, pp. 452-469.

Folta, T. B., Delmar, F. \& Wennberg, K. (2010). Hybrid entrepreneurship. Management Science, Vol. 56 No. 2, pp. 253-269.

Gibson-Graham, J. K. (1994). 'Stuffed if I know!': Reflections on post-modern feminist social research. Gender, Place and Culture: a journal of feminist geography, Vol. 1 No. 2, pp. 205-24.

Goss, J. D. \& Leinbach, T. R. (1996). Focus groups as alternative research practice: Experience with transmigrants in Indonesia. Area, Vol. 28 No. 2, pp. 115-23.

Grandey, A. A., \& Cropanzano, R. (1999). The conservation of resources model applied to work-family conflict and strain. Journal of Vocational Behavior, Vol. 54 No.2, pp. 350-370.

Greve, A., \& Salaff, J. W. (2003). Social networks and entrepreneurship. Entrepreneurship Theory and Practice, 28(1), 1-22.

Halbesleben, J. R., Harvey, J., \& Bolino, M. C. (2009). Too engaged? A conservation of resources view of the relationship between work engagement and work interference with family. Journal of Applied Psychology, Vol. 94 No.6, pp. 1452. 
Hayton, J. C., \& Cholakova, M. (2012). The role of affect in the creation and intentional pursuit of entrepreneurial ideas. Entrepreneurship Theory and Practice, 36(1), 41-68.

Herslund, L. \& Tanvig, H. (2012). When Life Style Entrepreneurs Establish MicroBusinesses in Rural Areas-The Case of Women in the Danish Countryside. InAdisa, R. S. (ed.) Rural Development - Contemporary Issues and Practices, pp. 375-392. Croatia: InTech

Ho, V. T., Wong, S. S., \& Lee, C. H. (2011). A tale of passion: Linking job passion and cognitive engagement to employee work performance. Journal of Management Studies, 48(1), 26-47.

Hobfoll, S. E. (1989). Conservation of resources. American Psychologist, Vol. 44 No. 3, pp. 513-524.

Hobfoll, S. E. (2001). Conservation of resources: A rejoinder to the commentaries. Applied Psychology-an International Review-Psychologie Appliquee-Revue Internationale, 50(3), 419-421.

Hobfoll, S. E., \& Lilly, R. S. (1993). Resource conservation as a strategy for community psychology. Journal of Community Psychology, 21(2), 128-148.

Jackson, P. \& Holbrook,B. (1995). Multiple meanings: Shopping and the cultural politics of identity. Environment and Planning A, Vol. 27, pp. 1913-30.

Kautonen, T., Down, S., \& Minniti, M. (2013). Ageing and entrepreneurial preferences. Small Business Economics, pp. 1-16.

Keltner, D., Gruenfeld, D. H., \& Anderson, C. (2003). Power, approach, and inhibition. Psychological Review, 110(2), 265-284.

Kimmel, J. \& Smith Conway, K. (2002). Who moonlights and why? Evidence from the SIPP. Industrial Relations: A Journal of Economy and Society, Vol. 40 No. 1, pp. 89-120. 
Klaukien, A., Shepherd, D. A., \& Patzelt, H. (2013). Passion for work, nonwork-related excitement, and innovation managers' decision to exploit new product opportunities. Journal of Product Innovation Management, 30(3), 574-588.

Langowitz, N. \& Minniti, M. (2007). The entrepreneurial propensity of women.

Entrepreneurship Theory \& Practice, Vol. 31 No. 3, pp. 341-364.

Major, V. S., Klein, K. J. \& Ehrhart, M. G. (2002). Work time, work interference with family, and psychological distress. Journal of Applied Psychology, Vol. 87 No. 3, pp. 427435.

Monsen, E. \& Urbig, D. (2009). Entrepreneurs and perceptions of compound risk. Moderating effects of efficacy and control beliefs. Frontiers of Entrepreneurship Research, Vol. 29 No. 6, pp 1-15.

The Ministry of Industry, Employment and Communication (2003). Företags-och anställningsformer i förändring. DS 2003:27. Stockholm: Fritzes Offentliga Publikationer.

Omorede, A., Thorgren, S., \& Wincent, J. (2013). Obsessive passion, competence, and performance in a project management context. International Journal of Project Management, 31(6), 877-888.

Parasuraman, S. \& Simmers, C. A. (2001). Type of employment, work-family conflict and well-being: a comparative study. Journal of Organizational Behavior, Vol. 22 No. 5, pp. 551-568.

Parasuraman, S., Greenhaus, J. H. \& Granrose, C. S. (1992). Role stressors, social support, and well-being among two-career couples. Journal of Organizational Behavior, Vol. 13 No. 4, pp. 339-356. 
Petrova, K. (2012). Part-time entrepreneurship and financial constraints: Evidence from the Panel Study of Entrepreneurial Dynamics. Small Business Economics, Vol. 39 No.2, pp. 473-493.

Raffiee, J., \& Feng, J. (2013). Should I quit my day job? A hybrid path to entrepreneurship. Academy of Management Journal. doi: 10.5465/amj.2012.0522

Renna, F. (2006). Moonlighting and Overtime: A Cross-Country Analysis. Journal of Labor Research, Vol. 27 No. 4, pp. 575-591.

Reynolds, P., Bygrave, W., Autio, E., Cox, L. W. \& Hay, M. (2002). Global Entrepreneurship Monitor. Kansas City: Kaufman Center.

Reynolds, P., Bygrave, W., \& Autio, E. (2003). Global Entrepreneurship Monitor Executive Report (p. 58). Babson Park/Kansas: Babson College, London Business School/Kaufman Foundation.

Richardson, M. S. (2002). A metaperspective for counseling practice: A response to the challenge of contextualism. Journal of Vocational Behavior, Vol. 61 No. 3, pp. 407423.

Statistics Sweden. (2010). Source: RAMS 2010

Taris, T. W., Schreurs, P. J. \& Schaufeli, W. B. (1999). Construct validity of the Maslach Burnout Inventory-General Survey: A two-sample examination of its factor structure and correlates. Work \& Stress, Vol. 13 No. 3, pp. 223-237.

Thorgren, S. \& Wincent, J. (2013). Passion and role opportunity search: Interfering effects of conflicts and overloads. International Journal of Stress Management, Vol. 20 No. 1, pp. 20-36.

Thorgren, S., \& Wincent, J. (in press). Passion and habitual entrepreneurship. International Small Business Journal. doi: 10.1177/0266242613487085 
Trip, J. J., \& Romein, A. (2013). Creative city policy and the gap with theory. European Planning Studies (ahead-of-print), pp. 1-20.

Vallerand, R. J., Blanchard, C., Mageau, G. A., Koestner, R., Ratelle, C., Léonard, M., Gagné, M. \& Marsolais, J. (2003). Les passions de l'ame: on obsessive and harmonious passion. Journal of Personality and Social Psychology, Vol. 85 No. 4, pp. 756-767.

Vallerand, R. J., Rousseau, F. L., Grouzet, F. M. E., Dumais, A., Grenier, S., \& Blanchard, C. M. (2006). Passion in sport: A look at determinants and affective experiences. Journal of Sport \& Exercise Psychology, 28(4), 454-478.

Wells, J. D., Hobfoll, S. E., \& Lavin, J. (1997). Resource loss, resource gain, and communal coping during pregnancy among women with multiple roles. Psychology of Women Quarterly, 21(4), 645-662.

Wells, J. D., Hobfoll, S. E., \& Lavin, J. (1999). When it rains, it pours: The greater impact of resource loss compared to gain on psychological distress. Personality and Social Psychology Bulletin, 25(9), 1172-1182.

Wennberg, K., Folta, T. \& Delmar, F. (2006). A real options model of stepwise entry into self-employment. In. Babson College Entrepreneurship Research Conference (BCERC).

Wincent, J. \& Örtqvist, D. (2009). Role stress and entrepreneurship research. International Entrepreneurship and Management Journal, Vol. 5 No. 1, pp. 1-22. 
Table 1 - Distribution of main motive for combining an employment with a side business

\section{Options (one choice only)}

1

2

3

4

5

6

7

8

9

10

11

12

13

14

15

16

Work more independently

Develop the business

Build a social network

Test my idea

Experience something new

Seasonal business only

The economic climate

Earn money

Professional broadening

Learning new things

Other motive

\section{Distribution}

Offered to become a partner

$3 \%$

$2 \%$

Test how it is to be an entrepreneur

$4 \%$

$7 \%$

$0 \%$

$6 \%$

Reduced hours within employment

$1 \%$

Work with something I'm passionate about

$34 \%$

$2 \%$

$4 \%$

I enjoy the business/work combination

$13 \%$

$1 \%$

$16 \%$

$1 \%$

$1 \%$
$5 \%$ 
Table 2 - Descriptive statistics and Pearson correlation coefficients ${ }^{\mathrm{a}}$

\begin{tabular}{|lll|llllllll|}
\hline & & & & & & & & & & \\
& Mean & s.d. & $\mathbf{1}$ & $\mathbf{2}$ & $\mathbf{3}$ & $\mathbf{4}$ & $\mathbf{5}$ & $\mathbf{6}$ & $\mathbf{8}$ \\
\hline 1. Passion & 0.343 & 0.476 & $(-)$ & & & & & & \\
2. Gender & 0.510 & 0.501 & 0.038 & $(-)$ & & & & & \\
3. Current age & 47.08 & 11.341 & -0.033 & -0.043 & $(-)$ & & & & \\
4. Married & 0.740 & 0.439 & -0.042 & -0.026 & 0.060 & $(-)$ & & & \\
5. Children & 0.800 & 0.401 & -0.100 & -0.127 & 0.493 & 0.343 & $(-)$ & & \\
6. University degree & 0.640 & 0.481 & 0.043 & -0.135 & -0.126 & -0.041 & 0.008 & $(-)$ & \\
7. Age at business start-up & 38.22 & 10.331 & 0.080 & -0.10 & 0.763 & 0.028 & 0.413 & -0.084 & $(-)$ & \\
8. Time spent on business & 17.99 & 17.757 & -0.179 & -0.015 & 0.071 & 0.030 & -0.090 & 0.066 & -0.068 & $(-)$ \\
\hline
\end{tabular}

$\mathrm{a}_{n=2}$ 262; Correlations greater than .12 are significant at $p<.05$. 
Table 3 - Results of logistic regression analysis on passion motive for combining wage work and a business

\begin{tabular}{lll}
\hline Variable & Model 1 & Model 2 \\
\hline Controls & 0.188 & 0.210 \\
Gender & 0.040 & -0.374 \\
Current age & -0.061 & 0.158 \\
Married & -0.500 & -0.747 \\
Children & 0.244 & 0.238 \\
University degree & & \\
& & \\
Main effects & & $0.619 *$ \\
Age at business start-up & & $-0.429 * *$ \\
Time spent on business & & \\
& & \\
Model diagnostics & 3.175 & 18.121 \\
Overall $\chi^{2}$ & {$[5]$} & {$[7]$} \\
[df] for overall $\chi^{2}$ & 0.018 & 0.106 \\
Nagelkerke $R^{2}$ & 0.010 & 0.062 \\
Adjusted $R^{2}(L L 0-L L 1) / L L 0$ & & 0.052 \\
$\Delta R^{2}$ & & \\
$*<0.05 ; * * p 0.01$ & &
\end{tabular}


Table 4 - Hybrid entrepreneurs' weekly time spent on the business

\begin{tabular}{|lll|}
\hline $\begin{array}{l}\text { Hours spent on the business } \\
\text { per week }\end{array}$ & Women & Men \\
\hline $\begin{array}{l}\text { By children } \\
\quad \text { No children }\end{array}$ & \\
Children 0 - 6 years & 16.47 & 23.66 \\
Children 7 - 12 years & 18.85 & 14.93 \\
Children 13-19 years & 14.36 & 17.00 \\
Children 20 - years & 12.57 & 19.63 \\
By age & 22.06 & 13.83 \\
20 -30 years & & \\
31-40 years & 15.75 & 16.44 \\
41-50 years & 15.71 & 19.12 \\
51-60 years & 14.29 & 17.16 \\
61- years & 22.11 & 14.53 \\
& 20.35 & 27.54 \\
\end{tabular}


Table 5 - Insights from focus group interviews

Theme

Individual

characteristics

Focus

Age, marital status, children, education, and the reasons for starting a business or becoming hybrids later in life.

Business engagement, The length of their businesses and wage work engagement, number of hours spent on it, the and their combination number of years functioning as hybrids and their future plans, the number of years employed for wages and their future plans, and their incomes from both the business and the wage work.

Work-business link Similarities and differences between activities conducted at work and in their business.

\section{Gained insights}

Those who started their business later in life did this because they needed time to think about what they wanted to do, and how they wanted, or could, do it. It was evident that there was no clear pattern here. Some were satisfied with the combination, whereas others wanted to become self-employed $100 \%$ but felt that financial difficulties did not allow them to leave their employment.

The informant's work was typically very different from their business. The reason for this was that they developed the business from a hobby or a dream/passion.

Reasons for being a hybrid
The motives for the self-employment, wage work, and the hybrid entrepreneurship.
Many hybrids started a business because it was something they felt passionate about and a hobby they wanted to develop. Most of the respondents enjoyed the wage work and also used it as a safety line, so they knew they would have a monthly income. 
Figure 1 - Estimated marginal means of hours in self-employment

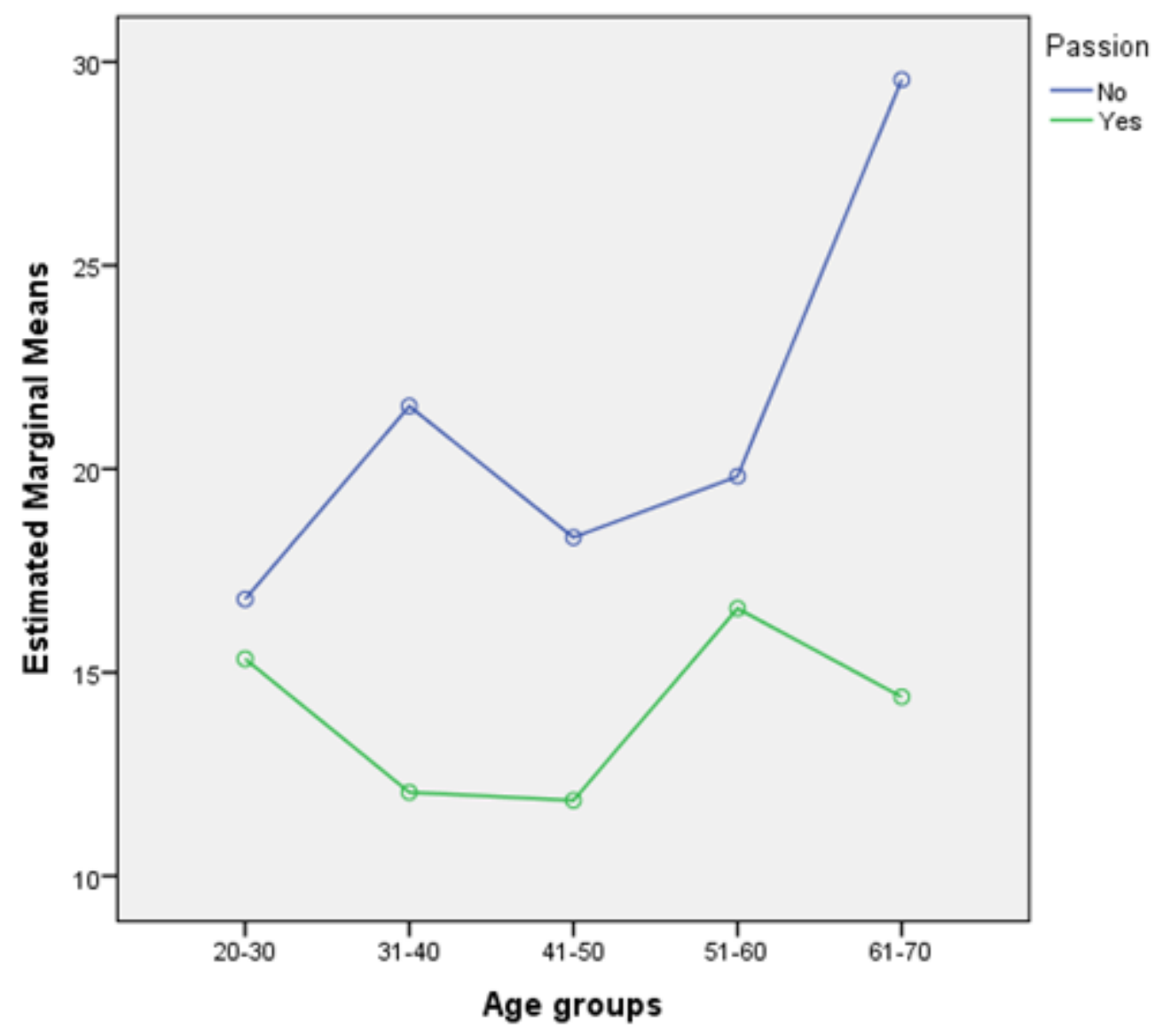

